\title{
Home rule and natural gas development in New York: civil fracking rights
}

\author{
Jeanne Simonelli ${ }^{1}$ \\ Wake Forest University, USA
}

\begin{abstract}
This paper explores the way community understanding of the impact and infrastructure associated with hydraulic fracturing (fracking) has translated into social action within the social, political, and ecological context of rural New York State, USA. How have residents confronted the boom-bust development of fracking, in the face of both actual drilling and the construction of supporting energy infrastructure? What avenues are open to residents as they plan for the long term sustainability of townships? Finally, on the level of both energy and rural development: if not gas, then what? This paper uses both actual and virtual interviews and oral histories to provide a case study of a struggle for environmental justice amidst conflicting visions and experiences of rural life in one New York region.
\end{abstract}

Key words: fracking, home rule, New York, social movements , Zapatistas

\section{Résumé}

Cet article explore comment la compréhension de la communauté de l'impact et de l'infrastructure associée avec la fracturation hydraulique (fracking) s'est traduite par l'action sociale dans le contexte social, politique et écologique de New York rural. Comment les habitants ont confronté le boom de la fracturation, confronter par des forages en cours, et la construction d'infrastructures de soutien? Quelles sont les voies ouvertes aux résidents à mesure qu'ils planifient la viabilité à long terme des cantons? Enfin, sur le plan de l'énergie et le développement rural: si pas de gaz, alors quoi? Cet article utilise des entrevues réelles et virtuelles et les histoires orales de fournir une étude de cas dans une région rurale de New York, sur la lutte pour la justice environnementale, au milieu des visions et les expériences contradictoires.

Mots clés: fracking, gouvernement autonome, État de New York, les mouvements sociaux, Zapatistes

\section{Resumen}

Este artículo explora la forma en la cual la comunidad entiende el impacto y la infraestructura asociada con fractura hidráulica (fracking), la cual se ha traducido en movimientos de acción social en el contexto, político, social y ecológico de las zonas rurales del Estado de Nueva York en EE. UU. ¿Cómo los residentes han confrontado el desarrollo del auge y caída del fracking, al igual que la construcción de infraestructura de apoyo frente a la perforación actual?, ¿Qué alternativas están disponibles para los residentes en relación a la planificación sustentable de los asentamientos a largo plazo? Por último, en relación al nivel de energía y desarrollo rural: ¿Si no es el gas, entonces qué? Este estudio utiliza ambas entrevistas, reales y virtuales, al igual que historias habladas para proporcionar un caso de estudio sobre los conflictos de justicia medioambiental en medio de visiones conflictivas y experiencias sobre la vida rural en una región de Nueva York.

Palabras claves: Fracking, autogobierno, Nueva York, movimientos sociales, Zapatistas

\footnotetext{
${ }^{1}$ Prof. Jeanne Simonelli, Professor Emerita, Department of Anthropology, Wake Forest University, Winston-Salem, NC, USA. Email: simonejm "at" wfu.edu. A brief version of this article was in SfAA News, February 1, 2013 (Simonelli and Earle 2013). I thank Dr. Duncan Earle for the insight and commentary he provided to that early publication. This is the third article in Willow, A.J. and Wylie, S. (eds.) 2014. "Energy, environment, engagement: encounters with hydraulic fracking", special section of the Journal of Political Ecology 21: 222-348.
} 
"Rebellion does not belong exclusively to the Zapatistas. It belongs to humanity. It is something to be celebrated. Everywhere, everyday, all the time" (Marcos 2014).

"In short, the fight against fracking in New York is now officially a citizen uprising" (Steingraber 2013).

\section{Introduction}

I came to Otsego County, New York twenty-five years ago, to a gentle valley nestled on the banks of the Susquehanna, and still call it home. For years I owned a ninety acre blueberry farm and wetlands which I sold just before the landmen came, offering gradually increasing sums of money for our natural gas mineral rights. Had they knocked on my door when I owned the land, I probably would have signed. Who knew?

My move took me to a little knoll, a $19^{\text {th }}$ century hunting camp suitable for hobbits, just above the red roofed barn of Grandpa Norfolk's farm. When the landmen came, he signed a lease: US\$3 an acre (MasonDixon Oil 2002), a far cry from the US\$5,000 acre signing bonuses received in Pennsylvania five years later (McGraw 2011). Who knew?

While living in the towns of Milford and Oneonta, I taught for thirteen years at SUNY-Oneonta, publishing Too wet to plow: the family farm in transition in 1987 (Simonelli and Winters 1987). That research documented the decline of dairy farming in surrounding counties in a climate of increasing economic stress. As the natural gas wars heated up in New York State, it was a logical step to wonder how many of the farms interviewed in Too wet had deeded their mineral rights to a myriad of out-of-state and outof-nation drilling companies; businesses hoping to extract gas through high volume, horizontal hydrofracking (see Willow 2014).

In upstate New York, in places described by the Environmental Protection Agency (EPA) as "remote", we are witnessing the way the penetration efforts of mature capital markets now involutes into the rural United States' "backwaters." In the wake of the recession and political changes abroad, new kinds of profit are squeezed out of natural resources at the expense of local people, as often happens in the Third World. Whether in rural New York, Mexico, or on the Navajo reservation, cultural activity occurs within ecosystems in which features of the natural environment are manipulated in the interest of economically-determined political power. As an applied anthropologist with field experiences that are united by the broad theme of change and choice in difficult situations, my interest is in documenting the way groups of people come together to gain voice and relative power under these constraints and how resulting social movements form and evolve as they work to achieve and maintain common goals.

Having worked with the Zapatistas (EZLN) in Chiapas, Mexico for seventeen years (Earle and Simonelli 2005), and witnessed the way that rebel group has attempted to develop autonomously and sustainably, it is interesting to reflect on how places of rural poverty and marginalization in the US respond to proposed and imposed development plans. The January 1, 1994 Zapatista uprising in Chiapas was a complex statement about the betrayal of the Mexican revolutionary and constitutional commitment to agrarian life and the nation's failure to protect the poor from internationally-dictated structural adjustments to development. Coinciding with the signing of NAFTA (North Atlantic Treaty Organization), the rebellion was a response to long-standing patterns of interaction, exploitation, and discrimination. In 1994, a month into the conflict, the Movement had already shifted from a focus on a popular armed war committed to the violent overthrow of the "bad government" to one of peaceful conjunction with civil society. The emergence of the EZLN over the next decade served as a political umbrella for the pursuit of development goals not just for its own members but also for those in other grassroots movements nationwide.

Since then, the Movement has been about listening and responding to those left out, and in the margins, and about facilitating communication. Their continued growth as a social movement is also a product of how those sectors have, in turn, listened to the Zapatistas and their messages, especially concerning the dangers of the government's globally-directed development proposals. The EZLN meets these challenges by the state through example, in the areas of education, production, and commercialization, and in 
the area of health. Moreover, as the first social movement to make effective and widespread use of the internet, the Zapatista model of organization and persistence has served as an example for indigenous and non-indigenous groups worldwide, in spite of the differing historical and political contexts surrounding these other struggles. To "be a Zapatista wherever you are" has meant embracing a model of engagement and action within the context of case specific response to globally pervasive challenges, as has occurred among grassroots organizations in New York (Earle and Simonelli 2011). In both cases, my goal has been to document the process that people use to achieve a particular end.

Consequently, this article will explore the ways community understanding of the impact and infrastructure associated with hydraulic fracturing (fracking) has translated into social action within the social, political and ecological context of rural New York. How do residents view the boom-bust development of fracking, in the face of actual drilling, and the construction of supporting energy infrastructure? What avenues are open to towns as they plan for their long term survival? Finally, on the level of both energy and rural development: if not gas, then what?

\section{Hydraulic fracturing in New York State: towns as communities}

The Marcellus Shale, which extends through much of the Appalachian Basin, and the deeper and more extensive Utica Shale, underlies twenty three counties in New York's Southern Tier, Central, and Finger Lakes regions. Beginning eleven years ago, New York landowners were offered gradually increasing signing bonuses for leasing their farmland and woodland for future natural gas ventures. At the time, looking at neighboring Pennsylvania, the industry assumed that drilling permits would be issued without much interference from State environmental regulators. But in 2008 New York declared a moratorium on horizontal drilling and opened a period of debate on the Department of Environmental Conservation's (DEC) 1,200 page Supplemental Environmental Impact Statement (SGEIS). The first comment period yielded 66,000 responses; a second round, ending on Jan. 12, 2013, resulted in 204,000 (Cha 2013). At the time of writing (March 2014), New York's governor Andrew Cuomo still awaits the results of a health impact study, and no formal decision has been made concerning horizontal drilling in New York, though vertical drilling has taken place for decades.

http://map.otsegocounty.com/Otsego County

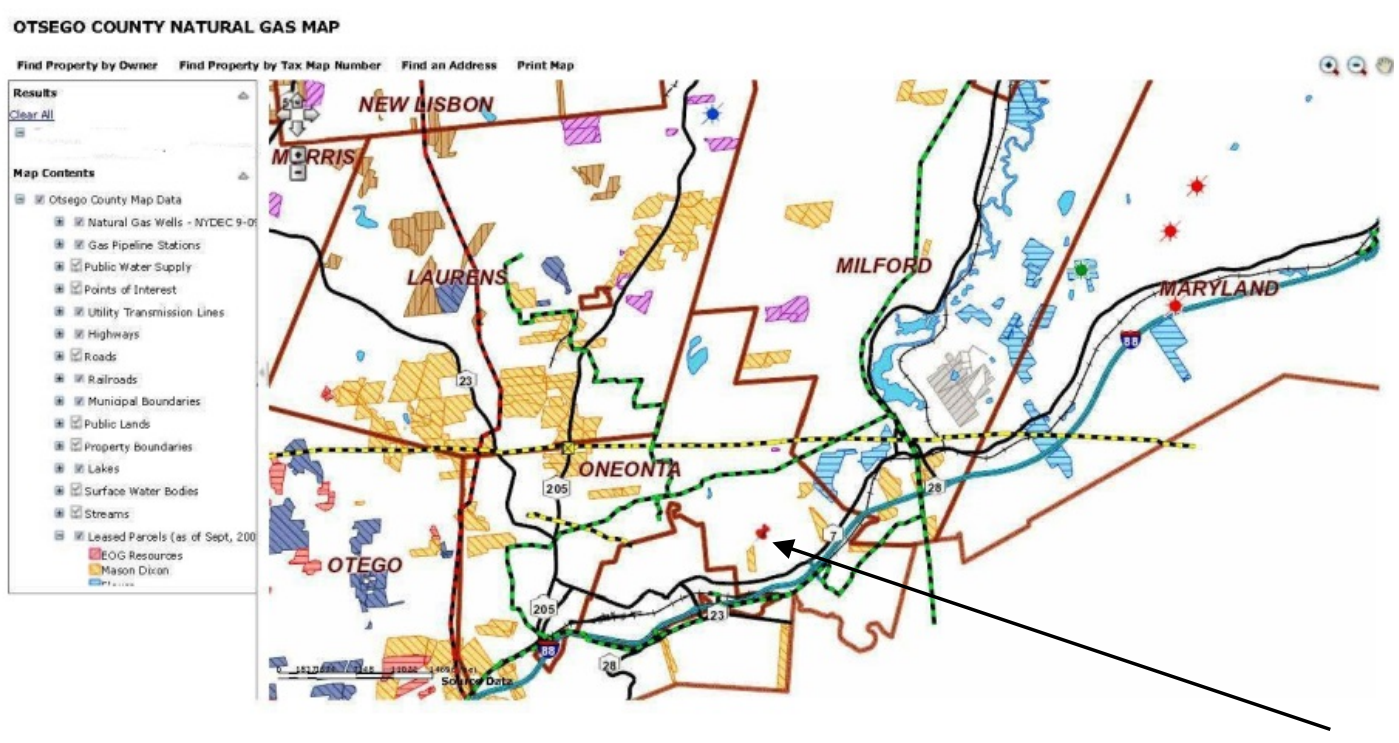

Figure 1: Natural gas leases in parts of Otsego County, NY 2011 with pin and arrow indicating author's home. Source: Otsego County. 
I returned to rural Otsego County (see Figures 1 and 2) as a permanent resident and retiree in 2012 to document and monitor the elaboration of unconventional energy development on the western edge of the NY's Catskill Mountains. This full time return supplemented previous residency from 1985 to 1999 and semi-annual visits from 2000 to 2012. It provided the opportunity to be a participating observer in a process of social action unseen in the region since the Delaware County Rent Wars of the mid-1800s, a movement that was also about unjust land use and land leasing (Cannon 2014).

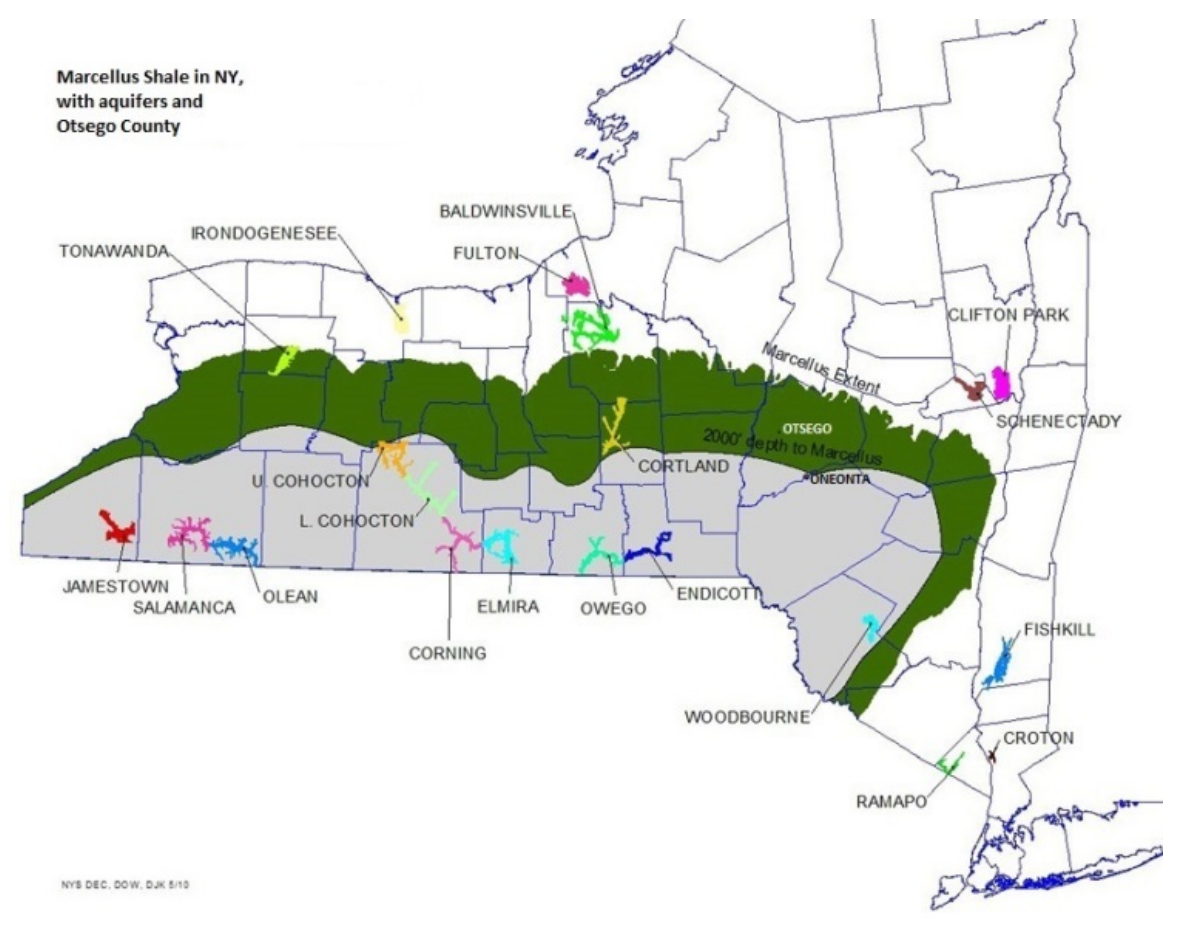

Figure 2: Otsego County (lettering in white) and Oneonta, NY in relationship to Marcellus Shale and New York State. Source: NYS DEC.

During 2012-2013, I attended meetings of town planning boards, regional grassroots anti-fracking organizations, and public forums held by local governments, industry spokespersons, and academic institutions, among others. As a painfully current regional issue, influencing many aspects of life from land purchases to electoral choices, almost every day was a source of a spontaneous conversation, culminating in what might be called a snowball sample of homeowners and landowners, struggling farmers, and committed activists. In this case, the bulk of my interaction was with members of anti-extraction grassroots organizations, as it is extremely difficult to develop a relationship of trust with both sides at the same time. Work by other anthropologists (Colosi 2013a, 2013b) provides in-depth documentation of the pro-gas landholding community.

Geographically, upstate New York is divided into environmentally distinct rural regions and each of these has produced its own grassroots groups, responding to particular threats in component counties. "Communities" generally coincide with legally and physically constrained townships where formal, binding decisions about development take place. I attended meetings and events in my own township and within about a twenty-five mile $(40 \mathrm{~km})$ radius of Oneonta, NY, occasionally joining statewide initiatives. Though these town meetings are essential to local planning, in the case of gas extraction and infrastructure, the virtual movement has been critical to the overall process of gathering data, in order to limit fracking through legal bans on industrial development. Listservs, websites and social media allow individuals and groups to stay 
connected to events and information that are local, regional, national and international. Moreover, these resources are like having a team of 150 researchers active at any one time, following up on scientific reports, press discussions, disaster reports, state agency deliberations, industry and stock exchange pronouncements and federal oversight processes nationwide. Thus, when not in New York I could remain active and involved, gleaning information from discussions and postings, while also observing how groups react and respond within a continual struggle for environmental and social control. As a result, this article uses both actual and virtual interviews and oral histories to provide a case study of a struggle for environmental justice amidst conflicting visions and experiences of rural life in one New York region.

Grassroots groups began forming in individual townships in 2007, often in areas contiguous to universities, where related research was taking place. For instance, Shaleshock was a product of Tompkins County, home to Cornell University, and describes itself as "a major outreach and information hub about fracking in the Southern Tier and Finger Lakes region, connecting people to the growing movement to protect our communities" (Shaleshock 2013). Like the organizational structure of Mexico's Zapatistas and the Occupy movement:

[It] is a loose network of groups and individuals. Landowners and renters. People with leases, and people without. No single person or group can represent Shaleshock as a whole...A couple of community forums, some documentary screenings, and a listening project, and Shaleshock had expanded from a small fluid organizing group to a movement consisting of many groups (Shaleshock 2013).

In Otsego County, home to two universities, the headwaters of the Susquehanna River, the Baseball Hall of Fame, and more dairy cows than people, a number of community organizations developed in 20072008. Sustainable Otsego was founded in 2007 and sustainability remains the focus of the group, "a loose, minimally structured network of local activists and supporters focused on Cooperstown and Otsego County" (Sustainable Otsego 2013). In 2009, local elections loomed. With the potential to gain some control over town and county governance, the group became more specifically active as "one of scores of organizations statewide in New York who oppose current drilling techniques as too unsafe and costly to be permitted" (Sustainable Otsego 2013).

As local community representatives and resident groups continued grappling with the question of how to control industrial development in their legally-defined townships, the Coalition Against Unsafe Drilling (CUAD) became a unifying site for advocacy in Otsego County, meeting monthly to compare experiences and plan integrated strategy. Other groups took on specific tasks. ${ }^{2}$ For instance, FLEASED helps landowners understand their leases and guides them into the legal process surrounding lease termination, which is no easy task (FLEASED 2013). FLEASED workshops were often attended by landowners who leased their land in the first few years of signing, were not necessarily against drilling, but couldn't figure out which company currently held the lease.

While monitored by individuals, the listservs attached to these and a multitude of other organizations expand the ability of groups to sift through and make sense of the explosive amount of information available each day. Press reports of environmental, health, political and economic events link groups across the globe. Scientific reports are far less frequent, but internet access streamlines the process by which these become available outside academia. Legal proceedings are monitored and often funded by organizations on both sides of the question and results are shared even before they become public. The judicious use of the internet and social media translates into political power as each region builds on work taking place in other towns, states and nations to track accidents, court decisions, technological advances, and civil actions. Like the Zapatistas, Occupy, and other social movements, the New York groups go through transitions as they move through the organizational life cycle; there are times to work outward and times to look inward as they develop and reassess tactics and strategy. The 204,000 comments submitted to DEC in January are an example of what

\footnotetext{
${ }^{2}$ http://otsegoadvocacy.org/.
} 
can be done while working outward. As biologist Sandra Steinberger stated, "In short, the fight against fracking in New York is now officially a citizen uprising" (Steingraber 2013). Conversely, movements can suffer from post-partum depression after a major milestone is reached. At that point, listserv discussions move to getting stabilized, planning, coalition building, and figuring out the next step, as occurs after each round of local and state elections.

New York has had powerful guidance from the example of Pennsylvania's largely unregulated model of gas extraction (see Hudgins and Poole 2014). NY groups work closely with community-based organizations in bordering counties who are living through the environmental, social, and economic impacts of extensive drilling. Community ethnographies describe the boom-bust cycle of drilling and the social and environmental side effects of the past eight years of change (Perry 2012, 2013). This experience by Pennsylvania residents helps balance the media interpretations on both sides of the issue (as presented in the films Gasland and Truthland) providing actual examples of the disruptive and destructive impacts of the extraction process on a day to day basis, as well as the economic benefits that have accrued to some individuals and the state. ${ }^{3}$ In New York and in Pennsylvania, community building is by no means limited to anti-gas groups (see Colosi 2013a\&b; JLCNY 2013). Landowner coalitions like the Joint Landowners Coalition of New York (JLCNY) have their own websites and legal teams, highlighting the dilemma of development wars: who gets to choose?

\section{Legal tools: home rule in New York}

Taking advantage of New York's moratorium, individual townships in the shale gas regions of the state have used home rule in an attempt to chart their own development course, by passing bans and moratoriums on fracking and the industrial development associated with it (Figure 3). In September 2011 the town of Dryden became the first of these to be sued by a natural gas drilling company in New York's Supreme Court, winning stage one of a lawsuit brought in 2012 and an appeal of that ruling on May 2, 2013. ${ }^{4}$ In another case, the town of Middlefield also prevailed, though it was sued by a landowner claiming that the town interfered with her right to use her land for drilling. These cases test the ability of individual towns to invoke home rule; that is, to use local zoning ordinances to prohibit heavy industrial economic development (Steinvurzel and Buno 2012). New York's recent Third Appellate Division ruling gives local government the authority to ban unconventional gas drilling and notes that oil and gas law does not reflect intent to "pre-empt a municipality's power to enact a local zoning ordinance banning all activities related to the exploration for, and the production or storage of, natural gas and petroleum within its borders" (Sieler 2013). Statutory authority for oil and gas regulations is found in the Oil, Gas and Solution Mining Law at ECL (Environmental Conservation Law) Sections 23-0303, 23-0305, 23-0502 and 23-0503 (Department of Environmental Conservation nd). In fact, New York has broader home rule powers than many other states:

Although it is not always clear, the New York Constitution does grant local governments fairly broad home rule powers to adopt local laws. The powers granted in Article IX of the Constitution and implemented by the Municipal Home Rule Law give authority to municipalities to act by local law with respect to (1) its "property, affairs, or government," and (2) other powers granted in statute whether or not they relate to its property, affairs, or government. However, many would argue that true "home rule" exists only if there is some constitutional curb on the power of the State to deal directly in the affairs of a local government (New York State Government nd; New York State 1998).

\footnotetext{
${ }^{3}$ The anti-fracking documentary Gasland, directed by Josh Fox, was released in 2011 and was nominated for an Academy Award. Truthland, financed by EID, was released in 2012 and was the response of the pro-fracking movement.

${ }^{4}$ Among numerous summaries of these cases see http://www.celdf.org/non-rights-based-fracking-ordinances-ny.
} 
In the months leading up to this these legal decisions, local organizations came together to provide information, legal aid, and political power to divided townships facing hard choices both for and against fracking.

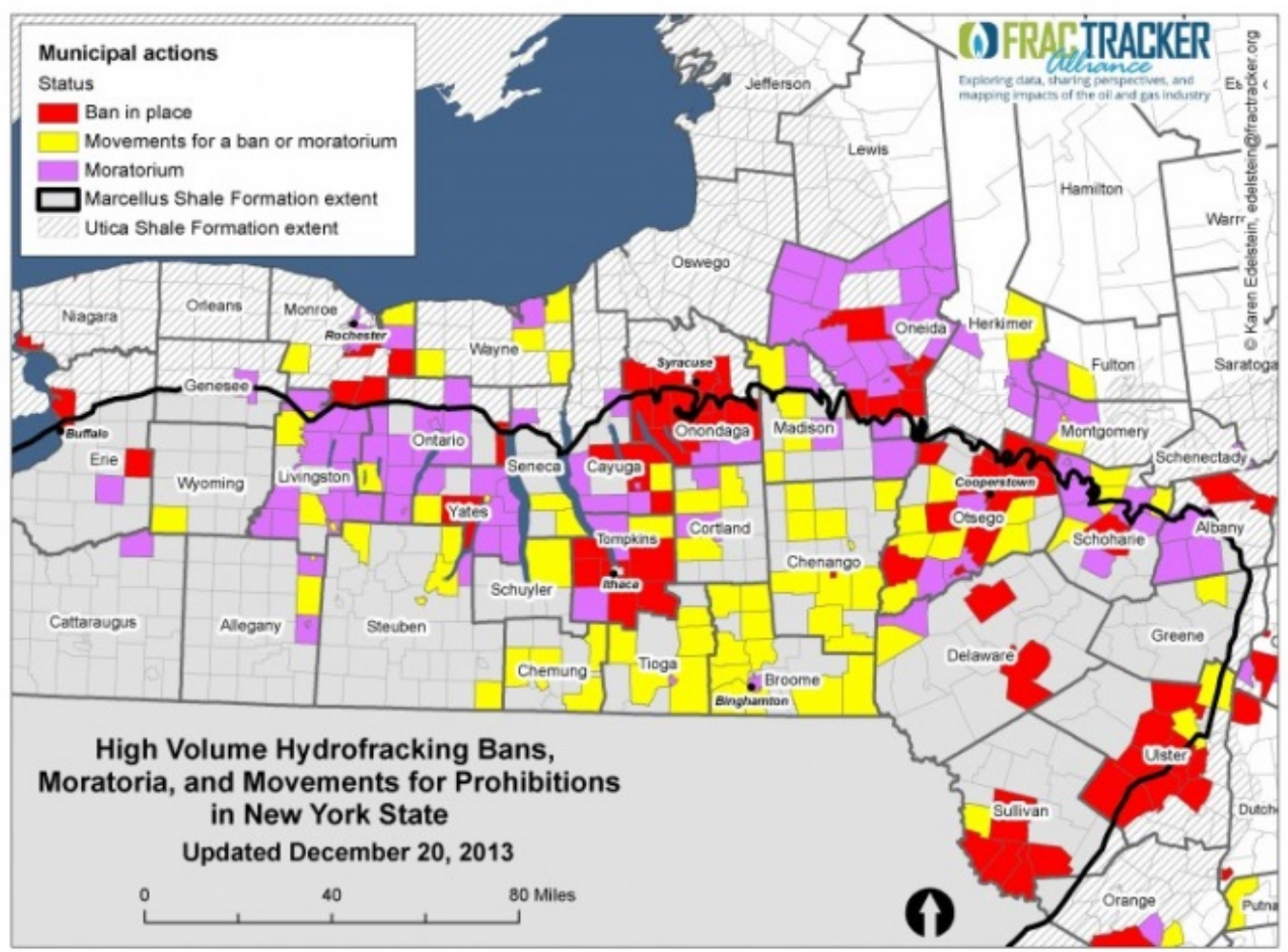

Figure 3: Bans, moratoria and movements for prohibitions in New York State. Source: Fractracker Alliance.

The Appellate Court ruling in 2013 prompted these lawyers, activists, and townspeople to construct a history of the home rule movement in New York. At my request, a number of individuals contributed their reminiscences of how the movement started and grew, posting these to various local list serves between May 2 and May 5, 2013. This virtual oral history is by no means complete, but provides a rich tapestry of grassroots action. $^{5}$

According to Anne Marie Garti, a local leader and attorney:

In 2008, everyone seemed to assume that we'd been stripped of home rule rights. People objected, sometimes in public, about the loss of this local power... I have a document dated 1/22/09, entitled Act to amend Section 23-0303 of the ECL, in which the offending clause was stricken...The first legal document I can find is the October 2009 newsletter published by Whiteman, Osterman and Hanna, LLP (WOH) (Mathes 2009). Todd Mathes wrote about home rule and gas drilling in an article NATURAL GAS AND MUNICIPAL CONSIDERATIONS... The negative declaration (SEQRA) by Middlefield, as part of the process to amend their master

\footnotetext{
${ }^{5}$ For Dryden's story see http://earthjustice.org/features/campaigns/the-story-of-dryden-the-town-that-fought-frackingand-is-winning.
} 
plan and zoning, is dated May 24, 2011. Michael Kenneally (New York Association of Towns) and Todd Mathes (WOH) published an article in the January / February 2010 issue of New York Zoning and Practice. They seem to be the first - as far as I've been able to find - but you never know what went on behind the scenes...

She adds:

Now I have to make a confession. The first time I heard about using zoning as a way to protect communities from HVHF [high volume horizontal fracturing] was from a pro-gas attorney Chris Denton - in the auditorium of Delaware Academy and Central School, in Delhi, New York, on July 24(?), 2008...during his pro-gas presentation with the geologist Don Zaengle...So we have to be thankful that Gastem targeted Otsego County first (Anne Marie Garti in 2013).

Gastem, a Canadian drilling company, completed a vertical frack of the Ross 1 well in Otsego County in November 2009, following work in two other locations (Gastem USA nd). At the time, Gastem had over 150 leases under their own name in the county and the well was being used to test the Oneida and Utica formations particularly, since the New York moratorium was limited to horizontal drilling in the Marcellus. In January, 2010 Gastem noted that they were:

...pleased to announce that the Ross No.1 vertical well was successfully completed and produced a sustained linear gas flow. All three zones of interest, namely the Marcellus Shale, the Oneida Sand and the Utica Shale produced gas, have good thickness and will be the subject of extensive programs in the coming months (Gastem, Inc 2010).

The well did not produce as expected and was eventually capped, but not before residents on the unpaved, hilly road approaching the site got a taste of the truck traffic and other industrial changes associated with drilling. As one activist remembers:

In the early stages we were not uniformly for a ban, we were just opposed to "unsafe gas drilling" and this was how the name of our regional coalition was chosen as the "Coalition Against Unsafe Gas Drilling" or CAUD. We began in late 2009 with a group of 8 individuals... and grew from there. One of the first items we focused on was how to help towns prepare resolutions supporting more study and a statewide moratorium. Resolutions did not carry the risk of retaliatory lawsuits, could be adopted more quickly than actual moratoria or bans, and served as a vehicle for public education and political momentum building. We prepared sample drafts of Proposed Resolutions for towns to consider on or about November 13, 2009. Early adopters of resolutions favoring a moratorium and more study were Middlefield (11/16/ 2009), Cherry Valley (11/23/2009), and Springfield (12/14/2009).

In the fall of 2010, lawyer Michelle Kennedy, recently relocated back to New York and now living in Cooperstown, was retained by Otsego 2000, a not-for-profit organization founded to protect the environmental, agricultural, scenic, cultural and historic resources of the county, for a very small stipend, to draft an initial legal memorandum summarizing the law on preemption. Her work was excellent and was eventually converted to a published law review article, but at the time she was a relatively new, solo practitioner and we felt we still needed a bigger name to back her up. We (Otsego 2000) then decided that we would retain Bond, Shoeneck \& King to write a memo on preemption that would support and build on Michelle's work. When the Executive Committee of B, S, \& K balked at working directly for Otsego 2000, we suggested that Middlefield retain them while Otsego 2000 agreed to finance the expense. 
The Town of Middlefield agreed to retain B, S \& K on March 10, 2011. Meanwhile, Rapport Myers and John Lyons of Grant \& Lyons, both representing Middlefield, and independently, the Slotjes [husband and wife lawyers working pro bono], were hard at work on the same theories. Most of the research was generously shared and the belief, now supported by multiple legal opinions, that towns could adopt enforceable bans as part of their police and/or zoning powers gained traction. John Lyon's (Lyons \& Grant) memorandum supporting this theory was dated January 6, 2011. Michelle Kennedy's law review article was published on January 26, 2011 (Kennedy 2011), the Bond Shoeneck \& King memo was shared with the community in May 2011, and two Slotje memoranda, dated January 27, 2011, and April 19, 2011, were widely distributed and read.

With reports circulating of the legal opinions that provided strong legal support for home rule, citizens began pressing their local town boards to take action. Before the Karen Edelstein maps (Figure 3) were a reality, I started manually keeping a list of towns that adopted resolutions, moratoria or bans. The earliest bans, I believe, were Sullivan County (adopting a ban on drilling on County lands on July 25, 2010) and the City of Pittsburgh (adopting a ban on November 24, 2010). In terms of bans adopted in Otsego County my records reflect the following: Otsego (5/13/2011); Middlefield (6/14/2011); Springfield (6/2011); Cherry Valley, (7/16/2011) (Dillingham 2013).

Though these decisions were critical to the future of the region, another commentator reminded readers to think of the implications of these decisions for the larger frack battle:

While the recent court decision is no doubt a watershed moment it is important to remember that fracking is a regional issue (if not a national and international one). The fight won't be won in Otsego County nor will it be won by the efforts of high profile names alone.

As this complex development war continues, frack action mobilization comes to resemble the Zapatista social movement in Chiapas. If the EZLN was the first virtual uprising, the frack battle is the first virtual civil rights movement, a struggle for autonomy in development decisions, fought out in the America hinterlands, by a US citizenry with no international rights. In fact, at the same time as the New York court revealed their decision concerning home rule, Oxfam published an extensive report entitled Community consent index: oil, gas and mining company public positions on free, prior, and informed consent (FPIC). According to the study:

As conflicts and controversies surrounding oil, gas, and mining operations have intensified in recent years, the principle of "free, prior, and informed consent" (FPIC) has emerged as a focal point in the broader debate around extractive industries. Oxfam defines FPIC as the principle that indigenous peoples and local communities must be adequately informed about oil, gas, and mining projects in a timely manner and should be given the opportunity to approve (or reject) a project prior to the commencement of operations (Voss and Greenspan 2012).

Rights under international law extend to indigenous communities, who have special status and entitlements reflecting their standing as distinct, self-determining peoples with collective rights. Nonindigenous communities in the US have no such opportunity to determine their collective future, unless they can do so under home rule provisions.

Though Dryden and Middlefield won the first appeal, lawyers for the gas industry filed a second appeal, this time to the New York State Court of Appeals. The State's highest court agreed to review the decisions in spite of the fact that Norse Energy, one of the original plaintiffs, has declared bankruptcy (Dolmetsch 2013). A decision is still expected in late spring 2014, and will either support or constrain the ability of New York townships to exercise their own version of FPIC. 


\section{Beyond wells: if you build it, they will drill}

New York has not yet made a final decision on whether fracking will be allowed, or what the regulatory process will ultimately look like. In spite of this, as part of the segmentation of gas extraction and exploitation, plans for a new thirty inch, buried gas transmission pipeline called the Constitution were unveiled in spring 2012. Pipelines are part of the fracking infrastructure and commodity chain, which ranges from compressing and moving the drilled gas (or oil) to mining sand to facilitate the frack (Pearson 2013).

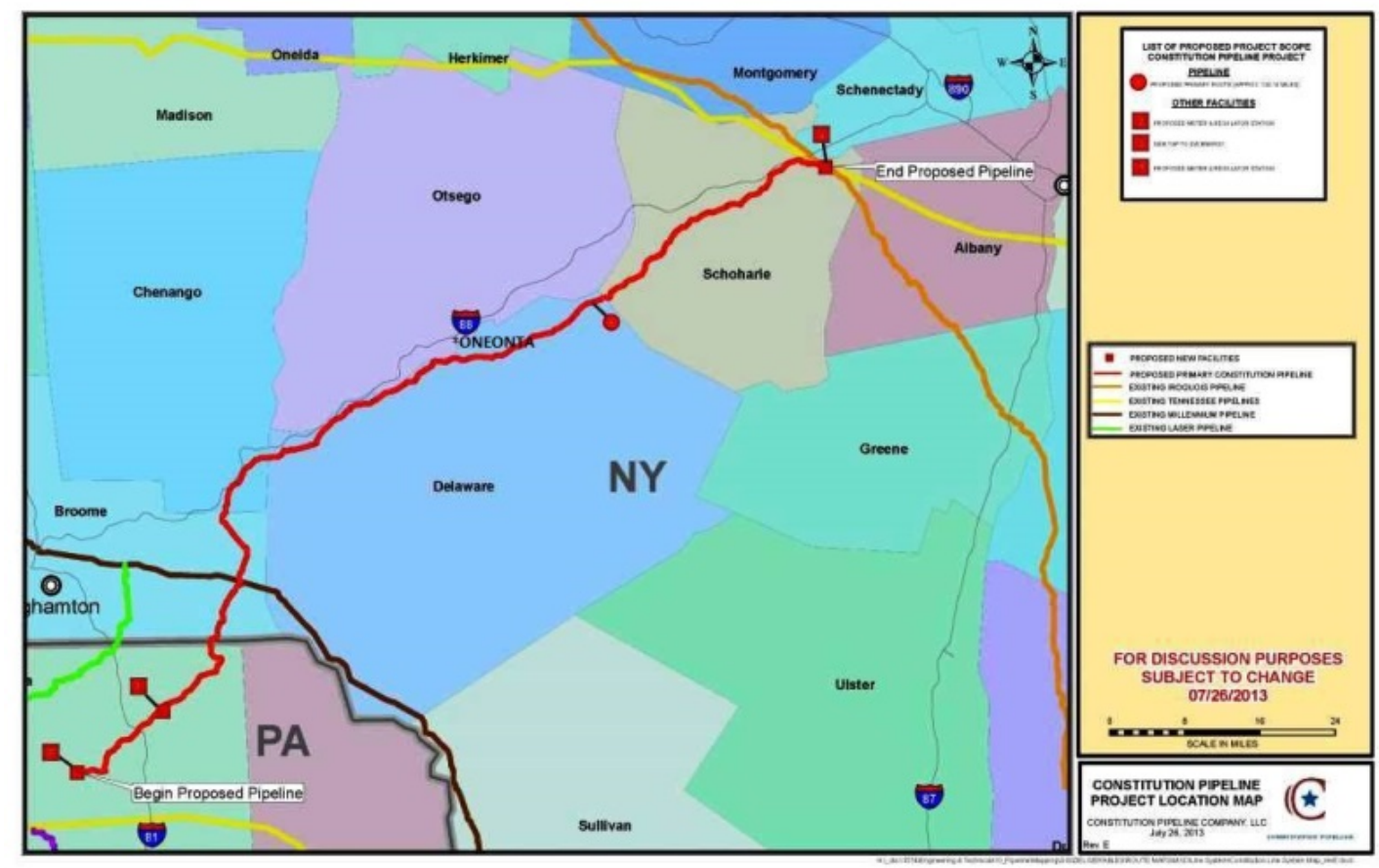

Figure 4: Route of Constitution Pipeline, in red. Source: Williams-Constitution.

Public concern over pipeline safety and its environmental impact has grown in response to the continuing battle surrounding the very visible Keystone Pipeline, slated to move tar sands oil from Canada to the Gulf Coast, and most recently opposed by Native American tribal leaders (Journal Staff 2013). However, Keystone is only one of many pipeline projects and battles taking place in the midst of the ongoing extraction fever (Tubb and Reed 2013).

Williams-Cabot, the energy consortium seeking a permit from the Federal Energy Regulatory Commission (FERC) to construct the Constitution pipeline through northern Pennsylvania and New York's Southern Tier, provides the following description of their proposed project:

The approximately 120-mile Constitution Pipeline is being designed with a capacity to transport 650,000 dekatherms of natural gas per day (enough natural gas to serve approximately 3 million homes). Buried underground, the 30 -inch pipeline would extend from Susquehanna County, Pa., to the Iroquois Gas Transmission and Tennessee Gas Pipeline systems in Schoharie County, N.Y. The proposed project route generally follows Interstate 88, stretching from Susquehanna County, Pa., into Broome County, N.Y., Chenango County, N.Y., Delaware County, N.Y., and terminating in Schoharie County, N.Y. (Williams 2013).

As community groups began to respond to the pipeline proposal, I revisited farms and farmers in Delaware and Otsego Counties, those who live in places with poetic and historical names like Prosser Hollow or Swart Hill, along the proposed route. This pipeline will carry Marcellus Gas from Brooklyn Township, PA, 
where Williams has already constructed a five engine compressor station, to Schoharie, New York, to connect with other major pipelines moving gas to the coasts. The company is seeking an easement through privately held land along its 120 mile $(193 \mathrm{~km})$ length. At present, only 60\% of landowners have allowed Williams survey teams and geologists onto their property to gather data. About $20 \%$ have formed a landowner coalition to try to block the process and new letters rescinding permission are filed with FERC each month (Marsh 2013). A remaining group refuses to communicate with the company in any form.

A community group called Stop the Pipeline and its related Unconstitutional Pipeline listserv has been instrumental in galvanizing interstate, multicounty support for the analysis of the project and a related movement to convince FERC not to issue the permit. Because this is an interstate pipeline, federal law in the US requires that an extensive public, accessible review take place, a process that is not required for identical projects that are intrastate. In 2012, Williams hosted a number of science fair style informational sessions in townships within the affected area, and voiced consternation and surprise at the opposition they met in New York. I attended three of these meetings and talked with project employees, most of whom were unfamiliar with the region's geographic and climatic range.

In addition to attending meetings (Figure 5), concerned individuals were given a set period to comment on the Williams-Cabot proposal, using the FERC on-line comment website. Under guidance of local leader Anne Marie Garti, who was studying law at Pace University, the affected communities learned how to construct a comment and how to submit it. Eventually, the Pace Environmental Litigation Clinic agreed to represent Stop the Pipeline in all legal matters. Garti completed legal training and passed the NY bar in October 2013.

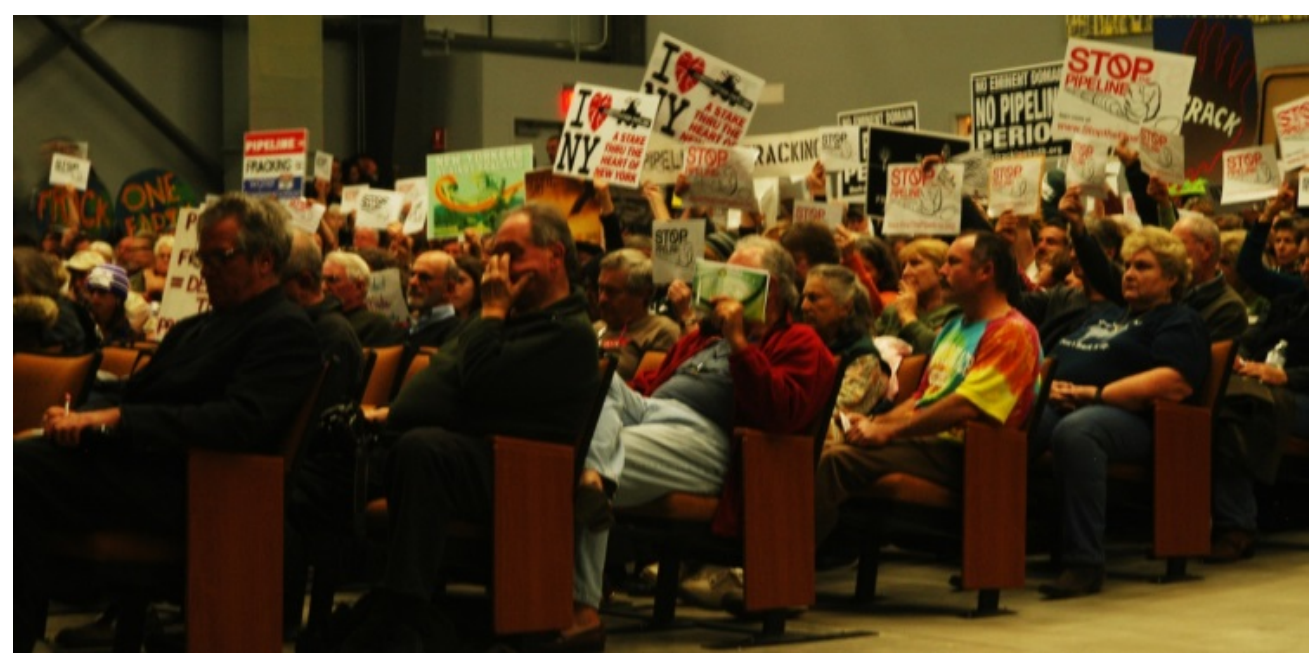

Figure 5: Community members speak out in Oneonta, NY. Source: STP.

A second round of community meetings, called "scoping hearings", were held in spring 2013. These were designed to elicit comments concerning the scope of the environmental review that should be done by Williams-Cabot contractors before the pipeline is permitted. Williams scheduled four meetings, carefully avoiding Oneonta, New York, a base-community for frack action. Eventually, a final meeting was scheduled in Oneonta, and FERC was forced to extend its scoping comment period. As an indication of community involvement, a required summary document created by Williams was thirty-five pages long and responded to the more than 800 comments submitted before the November $1^{\text {st }} 2012$ deadline (Constitution Pipeline Company 2012).

With the scoping phase completed, interested individuals and organizations were invited to become authorized interveners in the continuing process. Over 450 persons and groups filed with FERC, giving them the right to testify in any legal proceedings that might occur. Moreover, interveners receive notification of 
any action occurring with the environmental review, including the thousands of pages of comment and concerns filed by outside groups and agencies, and the equally long responses made by the Constitution project. On February 12, 2014 FERC issued a draft environmental impact statement (DEIS) stating that the pipeline would have a less than significant impact if mitigation steps are followed. Intervenors were given until April 7, 2014 to submit comments, attend meetings and prepare testimony for legal proceedings if permits are issued.

For upstate New York communities along a pipeline route which will undergo slight modifications until the permits are issued, the fight is about more than the movement of gas from the Susquehanna, Pennsylvania Marcellus gas fields to purported northeast markets. Though Williams still adamantly declares that their project has nothing to do with fracking New York, citizens argue that "if you build it, they will drill." The New York DEC has repeatedly stated that for New York to legalize fracking in the southern tier counties, the infrastructure to market the gas has to be in place. Moreover, though the local rhetoric has been "drill a well, bring a soldier home" analysis by listserv researchers continues to connect drilling, gas gluts, and pipelines to proposed LNG export terminals and international markets. In a letter to FERC dated August 13, 2012, Williams-Cabot asserted that the gas is to serve the Northeast US market - to supply US consumers (Hammons 2012). However, in a release issued December 19, 2013 Cabot announced a twenty year agreement to sell Marcellus-sourced gas to Japan, beginning on the in-service date of the expanded Dominion Cove Point export facility in Maryland (Cabot Oil and Gas 2013).

Currently there are twenty applications for permits to build liquefied gas export facilities. Dominion Cove Point, in coastal Maryland, is likely to be the first East Coast facility to be brought on line, having received approval to export from the DOE in the fall of 2013. The Obama administration is reviewing applications and if all win approval, the facilities could ship the equivalent of 41 percent of total U.S. production this year, according to Energy Department data (Efstathiou and Snyder 2013).

Because many of the individuals living in the New York shale gas regions are politically conservative, the ability to become energy self-sufficient through gas production was a powerful sell. If the gas flows out of the country, however, the short term payoff of an economic boom-bust cycle (estimated to be about two decades) will not counter the long term implications of drilling, even for this supportive segment of the population. For Williams-Cabot (and other project investors, including North Carolina's Piedmont Natural Gas), getting the pipeline in place now means huge competitive advantage if fracking begins in New York.

In opposing the pipeline, Pennsylvania and New York residents voice their objections in multiple domains, ranging from impacts on wetlands to noise levels, to air and water pollution. Williams-Cabot's lack of information concerning environmental history, climate and terrain prompted a passionate response by Schoharie Town Supervisor Gene Milone:

First and foremost there couldn't be a worse time for a project of this nature, not only in our town but the entire county, due to the energies that are being spent on the recovery effort [from massive flooding in 2011], something that is well known to the pipeline investors as well as its representatives...Our landscape is threatened once again, as well as peace of mind over its presence, generating no benefit to our community. It has the potential not only to create quality of life issues but it will depreciate property values as well. Undoubtedly, it will promote the issue of hydrofracking, a process not yet perfected. There will always be a concern pertaining to leakage and the potential for combustion. We as a community, once again, are being asked to shoulder these burdens for the multitudes just as we have been asked in the past...The payment for this is the crumbs from an extremely large pie (Milone 2012).

In addition to individual responses, environmental organizations also questioned the environmental and economic feasibility of the project, and made it clear that they saw the connections among the pipeline, fracking, and climate. Most significant were comments from the New York State DEC and the EPA. The former directs Williams to study the cumulative impacts in the event that fracking occurs (DEC 2012): 
Since the location of the proposed Project route has a high potential for development of natural gas extraction from Marcellus and Utica Shale formations, as indicated in the revised New York DEC draft Supplemental Generic Environmental Impact Statement on the Oil, Gas and Solution Mining Regulatory Program, September 7, 2011, the draft EIS must evaluate the cumulative environmental impacts associated with these potential activities.

EPA's letter includes the potential for air pollution in the wake of climate change, noting that "even as emissions are being reduced, climate change will continue to occur and therefore the effects of climate change on your project should be considered so that adaptations can be made as appropriate" (EPA 2012).

This latter directive is interesting, given the fact that the push for natural gas extraction has received support from legislation exempting it from the Clean Air and Clean Water Acts, in a process known as the "Halliburton Loophole" (see Willow and Wylie 2014). Both drilling and pipelines require compressor stations at gas in/gas out junctures, as would be needed to incorporate Marcellus gas flowing through/into the Constitution pipeline. These stations have their own serious concerns, as illustrated by an explosion and fire at a Williams compressor on May 14, 2013 (Kohut 2013). A very recent fire at the Williams compressor station in West Windsor, NY on Jan. 7, 2014 (WBNG 2014) brought back memories of an explosion caused by a lightning strike at the same site in the summer of 2012 (Mahoney 2012).

In 2012, the EPA, under Docket ID No. EPA-HQ-OAR-2008-0708-0866, proposed changes to federal rules on pollution from natural gas compressor station engines. The rule change would provide yet another industry exemption on pollution control technologies on compressor stations in areas that, according to EPA, are defined as "remote." According to 78 Fed. Reg. at 6675, any class location unit that has 10 or fewer buildings intended for human occupancy and no buildings with four or more stories within 220 yards (200 meters) on either side of the centerline of any continuous 1 mile $(1.6 \mathrm{~km})$ length of pipeline is remote. Operators will not be required to use technologies that have been used for decades on compressor engines and vehicles to greatly reduce emissions of hazardous air pollutants. In response to these changes, on April 1, 2013 a number of environmental groups petitioned the EPA for "Administrative Reconsideration of the Final Rule - National Emission Standards for Hazardous Air Pollutants for Reciprocating Internal Combustion Engines" (Environmental Groups 2013).

A similar rule allows the use of lesser quality pipe for pipelines in areas with lower-density rural housing concentrations, providing for higher short-term profits at huge environmental and health costs; what can be literally as well as figuratively forced out of the rural landscape. Health and safety issues are both obvious and overt. Pipeline and compressor accidents range from fires in above ground facilities such as those reported above to major underground explosions similar to the December 2012 blow-up of a pipeline underlying I-77 in West Virginia (Brinks 2013). The US Department of Transportation's Pipeline and Hazardous Safety Administration monitors incidents concerning pipelines on a yearly basis. The ten year average of "significant" incidents (causing damage over US\$50,000 per incident) was 282 per year, with property damages averaging US\$517,451,428 (USDOT 2014).

Less obvious health effects concern fugitive emissions and air and noise pollution near wells and along the length of gathering and transmission lines, including "normal" levels of gasses and volatile organic compounds that are a by-product of compressor station operation and shale gas production (Wylie and Albright 2014). While studies of pollution are often contradictory, pointing out that pollution from gas related infrastructure is far below that of a coal-fired power plant, reports from effected communities tell a different tale. In Pennsylvania, these reports, including increasing levels of ground level ozone, have moved the state's Department of Environmental Protection to strengthen regulations on new compressor stations (Hopey 2013).

The Constitution project includes two large compressor stations, one at each end of the pipeline. Yet materials provided at Williams-Cabot informational sessions cited a need for compressors every forty miles. It is this post-permit expansion that helps to fuel the concerns of landowners along the Constitution's length. Reports presented at monthly meetings of Stop the Pipeline, which has become a support system for individuals resisting settlement offers from company representatives, have shown how refusal to sign forces 
the continual tweaking of the pipeline's route to avoid non-compliant landowners. Landowners who refuse to allow the company access along the route will be subject to eminent domain should the pipeline be permitted. Eminent domain, broadly understood, is the power of the state to seize private property without the owner's consent. Historically, the most common uses of property taken by eminent domain are public facilities, highways, and railroads. Traditionally the power of eminent domain has been exercised for the construction of large public projects, but its use is beginning to be broadened to projects involving not 'public use' but 'public benefit' (Columbia 2014).

For landowners (and their neighbors) along the route, holding out against the threat of eminent domain takings is a hedge against infrastructural expansion when and if the pipeline is permitted. As opposed to land easements deeded to the company, which allow for additional construction and variable land use, seizure through eminent domain must occur in court and means that no future pipelines or other facilities can be constructed, only gas can be transported, and the landowner has no liability should an accident occur.

\section{Collateral damage: so what about people?}

Though there is continual commentary in the press and literature about environmental issues and fracking, there are few studies of people, their lives, their rights, and their futures in the context of resource extraction, regardless of whether they are for or against drilling (see Perry 2012, 2013; Hutchins and Poole 2014; Willow 2014). This subject surfaced recently in a conversation with a Navajo colleague as we drove through uranium-rich New Mexico, where a fracturing practice called "in situ leach mining" was being protested by Navajo families (Bitsoi 2012). I explained how rural populations in the northeast were facing the destruction of what might well be called their traditional way of life. "You're all Indians now," she said, commenting on this shared colonial experience.

Even as a UN Declaration on the Rights of Peasants and Other People Working in Rural Areas was finalized (Edelman 2012), our rural populations, native and non-native alike, have no such protections. A comparison with Chiapas and the Zapatistas illustrates that there is no structural difference; their marginalization is tied to their victimization by forces of market economies seeking profits when and where and as much as possible. In that setting it is often called internal colonialism. Using a global term and taking a local look, New York's landowners are smallholders involved in a social movement of grassroots origin, springing up in desperately divided communities, assisted by local groups and legal and education campaigns, in a region long beset by rural poverty (Fitchen 1981). Theirs is a protest against huge transnational forces (gas companies that are Norwegian, Canadian, Chinese and Dutch owned), against threats of vast and long term ecological destruction that has already begun, and the "end of country" as one author puts it (McGraw 2011). This is rural US colonization in the midst of hard, recessionary, desperate times - when people are most vulnerable to the landmen and fall victim to such environmental injustices as toxic and water table contamination, noise and air pollution, pipelines through wetlands, truck traffic, rising housing costs, and falling property values (Barth 2013). Though the historical and political conditions surrounding the Zapatista movement and the NY frack movements are different, and injustice is on a different scale, the threat to life and lifestyle gives rise to similar long term responses.

\section{If not gas, then what?}

On January 8, 2014, Governor Andrew Cuomo gave his yearly State of the State address in Albany, NY. Over two thousand protestors made what has become an annual trek, hoping to stay visible and be on site should Cuomo make a final pronouncement. Cuomo made no mention of drilling in his speech, and noted that the decision to frack will still be based on the results of the State's health study. The governor did emphasize economic development in general, focusing on aspects of the economic base brought by other long standing and/or sustainable upstate industries (Mahoney 2014). Turning Oneonta, New York into a clone of Montrose, Pennsylvania might bring short term income to a struggling farm population but only longitudinal research in areas like Susquehanna and Bradford counties in Pennsylvania can provide insight into what happens to other economic options in the long run. The already struggling dairy industry is dependent on unpolluted water and pasture, yet research from neighboring Pennsylvania points to a negative 
relationship between the gas extractive complex and the health of the dairy industry (Finkel, Selegean, Hays, and Kondamudi 2013).

Three other regional industries, wine, beer and Greek yogurt are also dependent on clean, reliable local water supplies. Cuomo's plans for 2014 feature a summit on how to get locally grown products to New York City markets, building on the organic food industry that already exists, though buyers have stated that they won't buy produce from areas where there is the potential for gas related contamination (see Royte 2012). The Governor also focused on increased investment in tourism, including new road signs to "guide motorists to relaxing destinations they can visit while traveling" (Mahoney 2014). Tourism is dependent on clean air, clear roads, and the sounds of silence. From the blue waters of Otsego Lake, to the banks of the Susquehanna, Otsego County sells its idyllic (and bucolic) character (Figure 6). Picture the 10,000 cars arriving for Baseball Hall of Fame Day competing for road space with 1,000 truck trips per well.

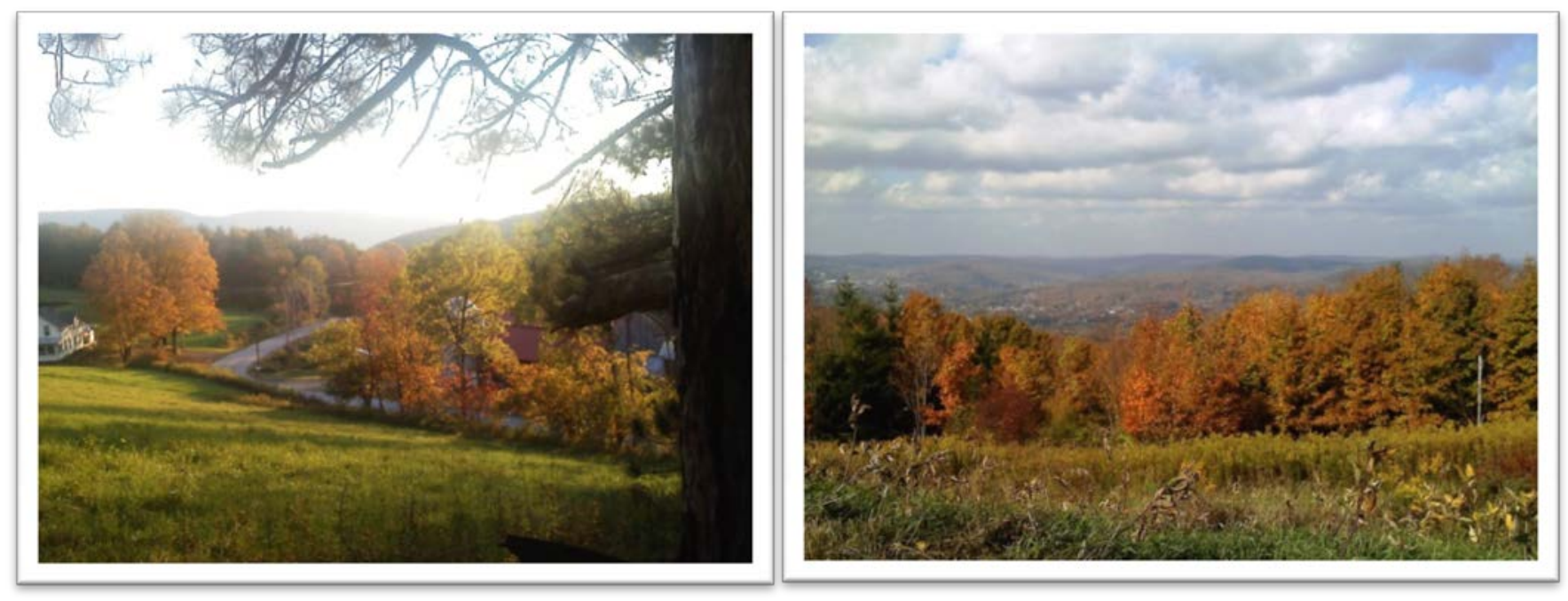

Figure 6: Susquehanna River Valley in Otsego County, looking towards Constitution Pipeline Route. Source: Jeanne Simonelli.

In upstate New York, community organization has been the first stage of resistance in this version of the development wars. Stage two is civil disobedience. In Horseheads, New York, as part of the energy commodity chain, a gas storage facility is being built in an unused salt cavern under Seneca Lake. Residents argue that this industrial infrastructure will destroy both tourism and the wine industry in the Finger Lakes region, and point to recent disasters in a similar gas storage facility near New Orleans. Protesting the continued work, fifteen people were arrested when they chained themselves to bulldozers. Three of these elected to go to jail rather than pay the fine (Editor 2012). On her release, biologist Sandra Steingraber stated:

I would do it again in a minute...Being new to civil disobedience, I'm still learning about its power and its limitations... and when to do it and when not (Bill Moyers.com staff 2013).

There is growing resistance to this market penetration at the land margins in rural America, and its maturation will continue in many forms. An extension of protest events through civil disobedience is uncivil disobedience. Suffice to say, in some states (e.g., New York, Colorado) many anti-frackers are aged Sixties hippies; in North Carolina, they are aged Panthers. The $21^{\text {st }}$ century adds new technological, virtual and economic dimensions to monkey-wrenching; for some, a more satisfying option than long term retirement care. There is much debate on and off the internet concerning whether this kind of protest is effective or prudent. 
The Zapatistas have always reminded us that there can be "a world where many worlds fit." They organize and make change at the level of subsistence because that is their identity; we, as Americans, may have to do it at the level of consumption, because that is our identity-logical responses given individual conditions. Just as the antifracking network needs to know who it is up against, at times buying a few shares of stock in an energy company in order to become stockholders, it also needs to know which products to boycott. This has become a growing movement on some college campuses. If there are more than 204,000 antifracking letter writers in New York State, that is a growing pool of consumers and aware voices that could easily make the connections as part of a pro-advocacy process along with an anti-advocacy program.

In that world where many worlds fit, proactive planning for communities is also critical. A by-product of town discussions about fracking, zoning, and development is a move to create long term development plans. As much as those opposed to fracking hate to think of defeat, all towns need a Plan A and a Plan B. If gas doesn't come, how will they create new avenues of development? If gas does come, what can the towns ask for, beyond road repair, which will make quality of life better for all citizens, not just those receiving lease payments?

Even if they don't put a gas well on my neighbor's leased property, like other landowners who don't lease, I'm concerned about real estate values. Land owners who do lease should be concerned, as some banks are opting not to issue mortgages on leased lands (Radow 2011). Moreover, appraisers are not sure how to value "lease-locked" properties, since in 2005 New York State passed a law allowing drillers to petition for compulsory integration (DEC 2005); gas companies can acquire "hostile" lease rights to enough land, as long as $60 \%$ of the needed space is leased. Full disclosure is required for all real estate listings and potential buyers are looking at lease maps before they buy. Compulsory integration has a recognized environmental impact for landowners, and if what has happened in Pennsylvania occurs in New York, it can also have a monetary impact on those whose agricultural properties become part of industrial development (Weidner 2009).

So, if not gas, then what? Governor Cuomo is pointing toward what we already have: tourism and agriculture. One other possibility includes the carbon credit market. With landowner coalitions formed and functional on both sides of the debate, this is an ideal time to examine the feasibility of using the land in this fashion. Currently, the pro-gas coalition (JLCNY) is rumored to represent 800,000 acres (324,000 ha.) and the anti-drilling organization (REALNYS) includes 64,059 (26,000 ha.) (REALNYS 2013). Carbon offsets and other positive alternatives (tax abatements for conservation commitments, etc.) can maximize landholding as an asset without selling out.

While bans and moratoriums that have been passed by receptive town boards utilizing home rule and zoning are heartening for the anti-drilling portion of the community, these results are not permanent. Changes in town board make-up can result in changes in town policy, without much involvement by community members. For this reason, a landmark fracking ban in Longmont, Colorado was achieved using a ballot initiative in November 2012. Working with the assistance of Food and Water Watch, town activists determined that the most enduring action would come from the Longmont electorate. Reversing the ban would be much harder than the New York town actions, as it would require a new ballot measure. November 2013 ballot initiatives in Colorado were successful in four other towns.

In the meantime, the number of towns with bans and moratoriums in New York increases daily. As of February 13, 2014 there were 72 bans, 105 moratoria, 87 movements for prohibitions (bans or moratoria) in the state (Edelstein 2013; Figure 3). They join similar movements nationwide and internationally, including France, Northern Ireland, and Germany, that have passed comprehensive bans. As mainstream Americans, our towns are not protected by Convention 169 of the International Labor Organization's Article 7 which states that "indigenous and tribal peoples have the right to "decide their own priorities for the process of development as it affects their lives, beliefs, institutions and spiritual well-being and the lands they occupy or otherwise use, and to exercise control over their economic, social and cultural development" (ILO 2013). Local communities in New York must work to create the legislation that will safeguard their right to live in a way that protects their health and wellbeing, and which opens a space for autonomy in the face of corporate industrial plans. This struggle continues amidst escalating plans to increase corporate power, this time under 
the guise of the Trans Pacific Partnership (TPP). If home rule is New York's autonomy, TPP is the region's NAFTA, a global partnership that threatens to undermine local control (Holland 2014; Huck 2014).

Ironically, the very first gas well ever drilled in the US was in Fredonia, NY in 1821, so the state has a long history of conventional drilling, as well as a landscape dotted with capped and abandoned wells. I first began teaching about drilling in the Marcellus Shale as part of a 2007 class in Applied Anthropology ten years following the first successful "slick water frack." At that time there was little information available in either the scientific or popular press. Though landmen began buying up NY leases in 2002, the first gas produced from the Marcellus was not until 2005, in Pennsylvania. But by 2007, in upstate New York townships, individuals were concerned enough to begin forming the groups described here.

Even as policymakers on all levels claim that they will base life-changing decisions on "the science", critical information and insight sometimes gets caught between urgency and validation. The need to maintain systematic methodology, obtain testable and replicable results, and submit to comprehensive critique and review is the strength and weakness of the process of scientific investigation. In the face of an avalanche of uncritical electronic information, with its twin threads of fetishization of scientific process/science, on the one hand, and complete misunderstanding and mistrust of it on the other, social science is particularly vulnerable (Paladino and Simonelli 2013).

In spite of the growing body of literature and experience concerning the environmental, health and social dangers of hydraulic fracturing and other energy production processes, the institutional responses and supporting science continue to come long after the damages have been done and many have suffered (Ibid 2013). Writing in 1976, Margaret Mead cautioned that "These are hazards so grave that every citizen should have a voice in deciding whether this is the road to energy independence we-or anyone-should take" (Townsend 2013).

As New Yorkers were penning comments to the Department of Environmental Conservation in December, 2013, the Zapatistas were marching in Chiapas, silently, saying, "Do you hear it? It is the sound of your world crumbling" (Molina 2013). In New York, grassroots organizations on both sides of the fracking debate were saying, listen: it is the sound of our people finding their voices (Figure 7). As EZLN spokesperson Marcos noted on January 1, 2014, "struggle is collective, but the decision to struggle is individual, personal, intimate, as is the decision to go on or give up" (Marcos 2014). Whatever the eventual outcome may be, it is the existence of this continuing social movement in New York that is notable and remarkable. Individuals have come together to learn to use the legal and political power available to them, in the interest of a collective struggle for both the local and global environment.
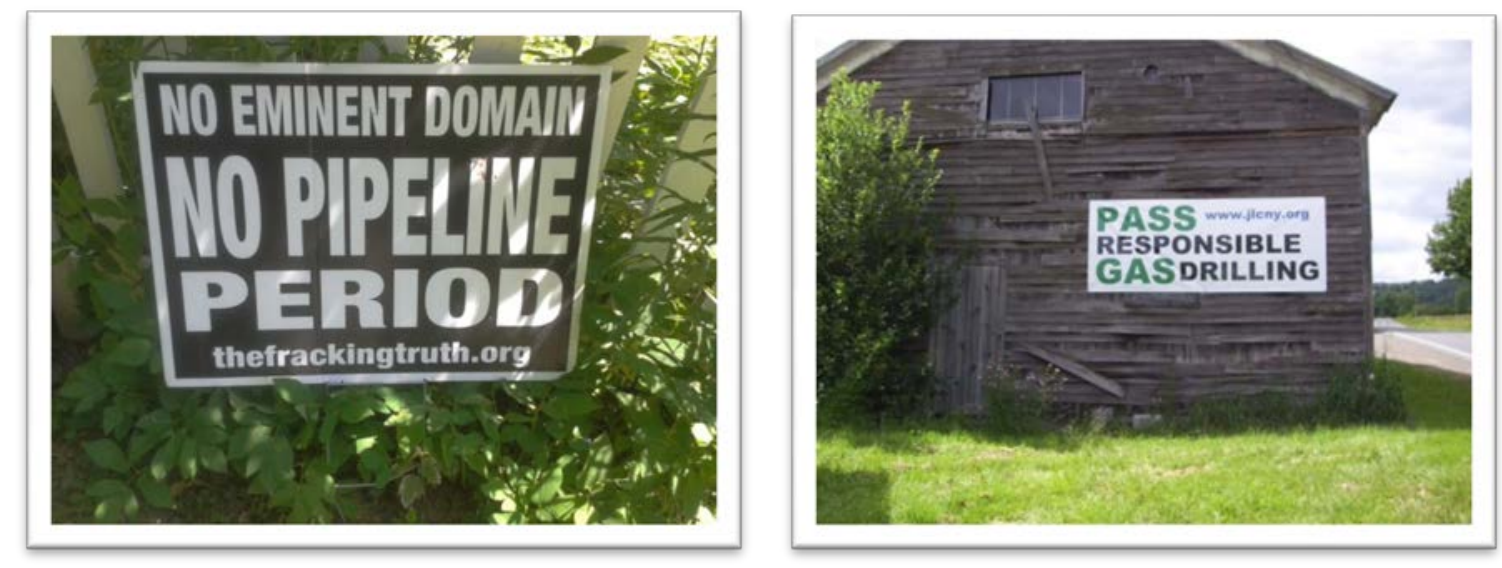

Figure 7: New Yorkers on both sides find their voices. Source: author and JLCNY. 


\section{References}

Barth, J.M. 2013. The economic impact of shale gas development on state and local economies: benefits, costs, and uncertainties. New Solutions 23(1): 85-101.

Bill Moyers.com staff. 2013. Anti-fracking activist Sandra Steingraber released from jail. BillMoyers.com April 30.

Bishop, C. 2014. Nine departments respond to blaze. Online [accessed January 7 2014]. http://www.wbng.com/news/local/Nine-departments- respond-to-blaze-239028421.html.

Bitsoi, A. L. 2012. The great debate: RDC tables legislation to reaffirm tribal uranium ban. Online October 42012 [accessed October 6 2012]. http://navajotimes.com/news/2012/1012/100412dog.php.

Brinks, T. 2013. Remembering the Sissonville pipeline explosion. Online [accessed December 11 2013].http://wvmetronews.com/2013/12/11/remembering-the-sissonville-pipeline-explosion/.

Cabot Oil and Gas. 2013. Cabot Oil and Gas corporation provides corporate update, announces agreement to provide natural gas to the Dominion Cove Point LNG. News release. Online December 192013 [accessed January 7 2014]. http://phx.corporate-ir.net/phoenix.zhtml?c=116492\&p=irolnewsArticle\&ID=1886053\&highlight.

Cannon, N.S. 2014. Reform/conflict: the anti-rent movement: brief introduction. Online [accessed January 13 2014]. http://www.oneonta.edu/library/dailylife/protest/index.html.

Cha, J.M. 2013. What 204,000 comments say about fracking. Huffington Post January 22.

Colosi, K. 2013a. Anthropology, extractive, industries and unconventional energy. Roundtable Presentation. Annual meeting of the American Anthropological Association, Chicago, IL. November 20-24 2013.

Colosi, K. 2013b. Home rule and the environmental politics of shale gas drilling in New York State. Paper Presented in Fracking and the Hydrocarbon Commodity Chain, Part I, Annual Meeting of the Society for Applied Anthropology, Denver, CO. March 19-23 2013.

Columbia University. 2014. What is eminent domain? Online [accessed January 7 2014]. http://www.columbia.edu/cu/cssn/expansion/infosheets/eminentdomain.pdf.

Constitution Pipeline Company. 2012 (October 24). Constitution responses to scoping 2012-1024.PDF. $\begin{array}{llll}\text { Online } & \text { [accessed } & \text { November } & 18\end{array}$ http://elibrary.ferc.gov/idmws/file_list.asp?accession_num=20121024-5122.

DEC (Department of Environmental Conservation). 2005. Online August 22005 [accessed May 142013 ]. http://www.dec.ny.gov/energy/1526.html.

DEC (Department of Environmental Conservation). 2012. NYS DEC comments, Nov. 7, 2012. Online $\begin{array}{lllllll}\text { November } & 12 & 2012 & \text { [accessed } & \text { May } & 4 & \text { 2013]. }\end{array}$ http://elibrary.FERC.gov/idmws/file_list.asp?accession_num=20121106-5145.

DEC (Department of Environmental Conservation). nd. Revised regulatory impact statement. Online [accessed May 2 2013]. http://www.dec.ny.gov/regulations/87440.html.

Dillingham, N. 2013. Brief history. Cooperstown, NY: unpublished historical reflection.

Dolmetsch, C. 2013. Pipeline \& Gas Journal's 33rd annual 500 report. Pipeline \& Gas Journal 240(11).

Earle, D. and J. Simonelli. 2005. Uprising of hope: sharing the Zapatista journey to alternative development. Walnut Creek: Alta Mira Press.

Earle, D. and J. Simonelli. 2011. Occupy Wall Street, consensus general assembly and the Zapatistas: into the American Zócalo. SfAA News November.

Edelman, M. 2012. One-third of humanity: peasant rights in the United Nations. Online October 122012 [accessed October 16 2012]. http://www.opendemocracy.net/marc-edelman/one-third-of-humanitypeasant-rights-in-united-nations.

Edelstein, K. 2013. Current high volume horizontal hydraulic fracturing drilling bans and moratoria in NY State. Online May 12013 [accessed May 12 2013]. http://www.fractracker.org/maps/ny-moratoria/.

Editor. 2012. Antifracktivists arrested in Seneca Lake action. Online September 62012 [accessed May 14 2013]. http://www.coalitiontoprotectnewyork.org/antifracktivists-arrested-in-seneca-lake-action/. 
Efstathiou, J. and J. Snyder. 2013. Obama seen expanding natural gas exports on production records. Online May 132013 [accessed May 13 2013]. http://www.bloomberg.com/news/2013-05-13/obama-seenexpanding-natural-gas-exports-on-production-records.html.

Environmental Groups. 2013. Petition for administrative reconsideration of the final rule - national emission standards for hazardous air pollutants for reciprocating internal combustion engines . Online April 1 2013 [accessed May 19 2013]. http://www.regulations.gov/\#!documentDetail;D=EPA-HQ-OAR2008-0708-1507.

EPA. 2012. Comments of the Environmental Protection Agency re the notice of intent to prepare an environmental impact statement for the Constitution Pipeline Project under PF12-9. Online October $102012 \quad$ [accessed $\quad$ November 442 2012]. http://elibrary.ferc.gov/idmws/file_list.asp?accession_num=20121016-0039.

Finkel, M., J. Selegean, J. Hays, and N. Kondamudi. 2013. Marcellus Shale drilling's impact on the dairy industry in Pennsylvania: a descriptive report. New Solutions 23(1): 189-202.

Fitchen, J.N. 1981. Poverty in rural America: A case study. Boulder, CO: Westview Press.

FLEASED. 2013. FLEASED. Online [accessed January 7 2013]. http://fleased.org/.

Garti, A.M. 2013. A brief history of the home rule movement in NY (e-mail interview, May 3 2013).

Gastem, Inc. 2010. Gastem Inc.: Ross No.1 initial results. Online January 272010 [accessed March 15 2012]. http://www.marketwire.com/press-release/gastem-inc-ross-no1-initial-results-tsx-venture-gmr1107977.htm.

Gastem, USA. nd. USA environmental concerns, mitigating actions and best practices Otsego County, NY. Online [accessed January 12 2013]. .

Hammons, W. H. 2012. Letter to Kimberly Bose, FERC. Washington, DC: on file, Docket \# PF12-9.

Holland, J. 2014. Trade expert: Why TPP- "NAFTA on steroids"- must be stopped. BillMoyers.com [accessed January 9 2014]. .

Hopey, D. 2013. Marcellus gas facilities near to one another or even linked are evaluated individually for pollution. Pittsburgh Post-Gazette October 6.

Huck, P. 2014. NAFTA failures a warning to treat TPP trade deal with caution. The New Zealand Herald. January 11.

Hudgins, A. and A. Poole. 2014. Framing fracking: private property, common resources, and regimes of governance. Journal of Political Ecology 21: 303-319.

ILO (International Labor Organization). 2013. Convention Number 169.

JLCNY (Joint Landowners Coalition of NY). 2013. Our Mission. Online May 212013 [accessed May 21 2013]. http://www.jlcny.org/site/index.php.

Journal Staff. 2013. Tribal leaders walk out of meeting about Keystone pipeline project. Rapid City Journal May 162013.

Kennedy, M.L. 2011. The exercise of local control over gas extraction. Fordham Environmental Law Review 22. draft.

Kohut, J. 2013. Fire, possible explosion at Susquehanna gas compressor station thought to be accidental. The Times-Tribune.com May 16.

Mahoney, E. 2012. Lightning causes compressor explosion. WBNG.com. July 232012.

Mahoney, J. 2014. Cuomo touts tax cuts, tech as '14 themes. The Oneonta Daily Star. January 92014.

Marcos, S. 2014. EZLN communiqué: 'when the dead silently speak out'. Text via Enlace Zapatista. English translation by Dorset Chiapas Solidarity and published by the Chiapas Support Committee. Online [accessed January 7, 2014]. http://roarmag.org/2014/01/subcomandante-marcos-ezln-anniversarycommunique/.

Marsh, J. 2013. Comments of JL Marsh and fourteen other individuals re the proposed Constitution Pipeline Project under PF12-9. Washington, DC: FERC. 
Mason-Dixon Oil. 2002 (August 22). Gas Drilling Lease; Mason-DixonOil and "J. Norfolk." On file at Otsego County Courthouse.

Mathes, T. 2009. Natural gas and municipal considerations. Online [accessed May 1 2013]. www.woh.com/img/newsletter/newsletter_4827464625.pdf.

McGraw, S. 2011. The end of country. New York: Random House.

McKenzie, L.M., R.Z. Witter, L.S. Newman, and J.L. Adgate. 2012. Human health risk assessment of air emissions from development of unconventional natural gas resources. Science of the Total Environment 424: 79-87.

Milone, G. 2012. Letters. Times Journal Online. Online August 12012 [accessed August 12012 ]. http://www.timesjournalonline.com/details.asp?id=74158.

Molina, M. 2013. Lessons in organization and dignity from the Zapatistas. Online January 32013 [accessed May 5 2013]. http://zapateando2.wordpress.com/2013/01/27/lessons-in-organization-and-dignityfrom-the-zapatistas/.

New York State. 1998. Adopting local laws in New York State. Online [accessed May 2 2013]. http://www.dos.ny.gov/lg/publications/Adopting_Local_Laws_in_New_York_State.pdf.

New York State Government. nd. Strengthening home rule. Online [accessed May 2 2013]. http://www.nyslocalgov.org/pdf/Strengthening_Home_Rule.pdf.

Norse Energy. 2012. Norse Energy Corp. Houston, TX: PDF.

Paladino, S. and J. Simonelli. 2013. Hazards so grave: anthropology and energy. Culture, Agriculture, Food and Environment 35(1):1-3.

Pearson, T. 2013. Frac sand mining in Wisconsin: understanding emerging conflicts and community organizing. Culture, Agriculture, Food and Environment 35(1): 30-40.

Perry, S.L. 2012. Development, land use and collective trauma: the Marcellus Shale gas boom in rural Pennsylvania. Culture, Agriculture, Food and Environment 34(1):81-92.

Perry, S.L 2013. Using ethnography to monitor the community health implications of onshore unconventional oil and gas developments: examples from Pennsylvania's Marcellus Shale. New Solutions 23(1): 33-53.

Radow, E.N. 2011. Homeowners and gas drilling leases: boon or bust? New York State Bar Association Journal 83(9): 10-12, 14-21.

REALNYS. 2013. Latest numbers. Online May 192013 [accessed May 19 2013]. .

Royte, E. 2012. Fracking our food supply. The Nation. December 17.

Shaleshock. 2013. About. Online [accessed Janaury 4 2014]. http://shaleshock.org/about-2/.

Sieler, C. 2013. Fracking critics say New York appellate decision is major loss for shale gas drilling. Online May 22013 [accessed May 2 2013]. http://www.timesunion.com/local/article/Frackingcritics-say-New-York-appellate-decision-4482964.php.

Simonelli, J. and D. Earle. 2013. Civil fracking rights: Community response to natural gas development in NY. SfAA News. February 2013.

Simonelli, J. and C. Winters. 1987. Too wet to plow: the family farm in transition. New York: New Amsterdam Press.

Steingraber, S. 2013. Welcome to day 1 of life after the close of the DEC public comment period! Online [accessed January 9 2014] http://us4.campaignarchive1.com/?u=9691e612c7b1b9a9a04bf1f41\&id=96ca606b08\&e=dc6316f1f0.

Steinvurzel, R., and J. Buno. 2012. Municipalities and natural gas extraction... what the frack? New York Law Journal. Online May $23 \quad 2012$ [accessed May 2 2013]. www.newyorklawjournal.com/PubArticleNY.jsp?id+12025556000129.

Sustainable Otsego. 2013. About Sustainable Otsego. Online [accessed May 9 2013]. http://www.sustainableotsego.org/about-sustainable-otsego. 
Townsend, P. 2013. Energy policy in American faith communities: "the power to change. Culture, Agriculture, Food and Environment) 35(1): 4-15.

USDOT. 2014. Pipeline and hazardous materials pipeline and safety administration. U.S. Department of Transportation's Pipeline and Hazardous Materials Safety Administration (PHMSA), Office of Pipeline Safety (OPS).

Voss, M., and E. Greenspan. 2012. Community consent index: oil, gas and mining company public positions on free, prior, and informed consent (FPIC). Research Backgrounder series. Oxfam America.

Weidner, K. 2009. Natural gas exploration: a landowners guide to financial management. University Park: The Pennsylvania State University.

Wylie, S. and L. Albright. 2014. WellWatch: reflections on designing digital media for multi-sited paraethnography. Journal of Political Ecology 21: 320-348.

Williams. 2012. Williams analysts day powerpoint. Online May 222012 [acessed June 22 2012]. http://www.b2i.us/Profiles/Investor/Investor.asp?BzID=630\&from=dl\&ID=136006\&myID=136006\& $\mathrm{L}=\mathrm{i} \&$ Validate $=3 \& \mathrm{I}$.

Williams. 2013. Constitution Pipeline. Online April 232013 [accessed May 15 2013]. http://constitutionpipeline.com/.

Willow, A. 2014. The new politics of environmental degradation: un/expected landscapes of disempowerment and vulnerability. Journal of Political Ecology 21: 237-257. 